This is a pre-print version;

The final version of the article was published in Evaluation and Program Planning

Volume 35, Issue 1 (2012), pp.148-153 and can be accessed at http://dx.doi.org/10.1016/j.evalprogplan.2010.11.006

\title{
Challenging the international peacebuilding evaluation discourse with qualitative methodologies
}

Tobias Denskus

\begin{abstract}
Monitoring and evaluating international peacebuilding efforts has become more sophisticated over the past years, but still relies on managerial approaches that often do not capture the complexity of war, peace and the grey areas in between. The article argues that organisations should embrace qualitative approaches more widely and introduces ethnographic vignettes as one example to explain the complexity of post-conflict situations. By understanding the personal dimension, the life- and work-styles of international peacebuilders, the current evaluation discourse can become more meaningful-both for organisational learning and sustainable peace efforts on the ground. The article ends by highlighting some approaches that deserve more attention and that promise to help to critically enhance current and future debates about the evaluation of peacebuilding.
\end{abstract}

Keywords: peacebuilding, conflict, reflective practice, complexity theory, ethnography, evaluation

When I started to work on the second draft of my article I had a few random encounters with the professional and personal lives (sometimes difficult to differentiate, especially in a conflict or post-war space) of friends and colleagues who work in international development and who are international consultants, evaluators or international aid workers who also work on monitoring and evaluation issues. These (virtual) encounters such as blog posts, uploaded pictures on facebook or status messages on Skype, LinkedIn or Twitter not only give insights into the 'real life' realities of working in 'dangerous places', but also into the 'life worlds' of professionals of the peace and aid industry that often seem to have little to do with the reports 
This is a pre-print version;

The final version of the article was published in Evaluation and Program Planning Volume 35, Issue 1 (2012), pp.148-153 and can be accessed at http://dx.doi.org/10.1016/j.evalprogplan.2010.11.006

they write or the organisational realities 'on the ground'. In short, although this is an open secret (see for example development-related blogs such as Bill Easterly's aidwatch, Aid Thoughts, Chris Blattman’s or Daniel Esser’s blogs [http://aidwatchers.com/; http://aidthoughts.org/; http://chrisblattman.com/; http://danielesser.org ] that discuss the complexities of aid openly and from a variety of viewpoints and on a variety of topics that often are very relevant in postconflict situations), the lived realities of those working, travelling (usually a lot), advising, monitoring, evaluating and researching peacebuilding interventions is hardly ever taken into consideration when the 20 page draft report (made livelier with a few pictures from participatory workshops) is submitted or the relevance of the OECD/DAC evaluation guidelines for peacebuilding are discussed. Beyond the anecdotal evidence and stories, there is an important issue and critique that this short article wants to highlight, namely that the quest for 'better' or more 'appropriate' evaluation frameworks, tools, guidelines and handbooks needs to take the attitudes, mindset and behaviour (cf. Chambers 2006) of 'Aidland' (Eyben 2006) into consideration to get a more comprehensive picture of how peacebuilding works and why it often does not work according to 'plan'. The second main argument of this paper is that rather than spending more time and effort on quantitative evaluation methodologies an increased interest in aid relationships (e.g. Eyben 2006; Mosse and Lewis 2005), qualitative methods and ethnographic research will strengthen monitoring and evaluation of peacebuilding work or aid work in 'difficult' environments and ultimately lead to increased learning possibilities for everyone involved. 
This is a pre-print version;

The final version of the article was published in Evaluation and Program Planning Volume 35, Issue 1 (2012), pp.148-153 and can be accessed at http://dx.doi.org/10.1016/j.evalprogplan.2010.11.006

Outline of the article

The article starts by presenting three different ethnographic vignettes to outline the reality of post-conflict situations and the embeddness of international development organizations, peacebuilders and local citizens in these situations. By understanding the life- and workstyles of those who life in these realties is it possible to challenge currently dominating managerial approaches to monitoring and evaluation of international peacebuilding efforts. The second part presents some of the currently used evaluation tools and frameworks as well as the discourse behind it, i.e. the language used and the professional debates that shape the perception of how peace-related work should be evaluated. The article ends by highlighting some approaches that deserve more attention and that promise to help in critically enhancing current and future debates about approaching evaluation of peacebuilding.

Peacebuilding lifestyles

\section{Bintu in Sierra Leone}

'Bintu, on the other hand, was attractive, and men fancied her. As a result, she had to do crocrogy (criminal business-in this case going out with several men) in order to sustain her female friend. Her boyfriend was aware of her male affairs but had to comply because he was a powerless civilian without any source of income or assets. Bintu became his financial provider, too. During Sherman's [A commander in the rebel movement National Patriotic Front of Liberia (NPFL)] absence, Bintu’s “loving business” sustained them all. 
This is a pre-print version;

The final version of the article was published in Evaluation and Program Planning Volume 35, Issue 1 (2012), pp.148-153 and can be accessed at http://dx.doi.org/10.1016/j.evalprogplan.2010.11.006

I never really used to enjoy going out with these fighters. I was doing these things because I wanted to survive-do you understand? It was no enjoyment at all. I just wanted to survive, because the crime they put on me was very bad. Reconnaissance-if they caught you for that they would kill you. So I was forced to make life "sweet" for myself. [...] So I just had to strain. You know strain-to the full meaning of the word. [...]

At this point Bintu also started taking interest in the looting economy. Joining Sherman at the front, she took up arms and fought as an irregular. Her war experience had numbed her so completely that she spoke of going to the battlefield as a "relief." Yet her account also highlights the immense feeling of empowerment that many young rebel soldiers experienced when they carried arms. Pushing people in any direction they wished was a small sensation to marginal youth and even more so to young people who had experienced the powerlessness of being a civilian in war time [...]' (Utas 2005: 422-423).

This short vignette from an article by anthropologist Mats Utas, based on his year-long field research in Liberia in 1997/1998, cannot do justice to the horrors, the complexities, the opportunities or the agency of people in war zones. Also, questions of how to 'evaluate' the behaviour of a girl like Bintu in this 'no war, no peace' (Richards 2005) limbo seem almost unfair to ask given the enormity of her sufferings and the challenges of her movement through the warfare in Liberia. And yet, one could easily see Bintu appearing (or disappearing) in a 'demobilisation camp' run be the UN, or join a ‘training' run by an international development agency that has entered the country once 'the war' was declared over and the country was ready 
This is a pre-print version;

The final version of the article was published in Evaluation and Program Planning Volume 35, Issue 1 (2012), pp.148-153 and can be accessed at http://dx.doi.org/10.1016/j.evalprogplan.2010.11.006

for 'post-conflict peacebuilding'. Bintu would morph into a number in a statistic that would then become part of a project report that would form the basis for the mid-term evaluation by an outside ‘mission'. Given her outgoing behaviour, Bintu may even be part of the 'focus group’ that the European evaluation team talks to and given her skills, insights and memories from the warzones she would quickly figure out what the outsiders want to hear and will praise the ‘comprehensive approach' to demobilization with a 'particular focus on vulnerable groups such as women, girls and war widows'. From soldier to girlfriend to 'beneficiary', Bintu would once again be labelled by oustiders and would have to acquire a new identity to navigate through the complex situation of 'post-war'.

Engaging with the complexities of war zones and transitions from an anthropological or qualitative research perspective is not just a means of storytelling or to present anecdotal 'evidence' from 'the field'. It is the tip of the iceberg of how war and peace are unperceived and that has a strong and direct impact on how and why we carry out evaluation in such environments the way many organizations and professionals do: By trying to comply with abstract evaluation methods and rationales to present an orderly, technocraticized and depoliticized version of 'impact' that often treats the end of war as 'zero hour' from which peacebuilding initiatives can be launched. Carolyn Nordstrom, another anthropologist who spent many years at the frontlines of conflict and war in Mozambique, Sri Lanka and Angola, puts this into a broader perspective when she outlines some of the features of the 'shadows of war' as she calls the multi-faceted spaces between the frontlines and corporate offices in Northern countries: 
This is a pre-print version;

The final version of the article was published in Evaluation and Program Planning Volume 35, Issue 1 (2012), pp.148-153 and can be accessed at http://dx.doi.org/10.1016/j.evalprogplan.2010.11.006

My point is that when people are largely unaware of the extent to which violence, human rights abuses, and criminal activities are operationalized within the political, economic, legal, and social frameworks of their society, they will be largely unable to correct them. [...] It is to say that these [criminal] activities did not take place outside the scope of normal institutional life: where they occurred, they occurred as part and parcel of "the way things are done.” Society emerges through these processes; they become institutionalized (2004: 148-149).

And what Nordstrom describes for the 'bad' ways and means to interact is also true for many other areas, e.g. civil society engagement or the participation in decision-making; complex, historical, alternative, subversive or abusive relationships form the pre-war or conflict social fabric, the in-war and post-war social fabric and discontinuities, changes and stability go hand in hand in such a fragile situations.

Johannes in the Democratic Republic of Congo

'After three weeks in Goma, I still feel that I have not really arrived. Due to security constraints and fuel shortfalls which prevent MONUC to provide the obligatory escortes [sic!], I have not been able to leave the city to which I am therefore confined. Moving between the hotel the office and a few other places, such as a fitness room at one of the MONUC bases and one of the few restaurants for expatriates, I have not been able to discover life beyond this microcosmos of a UN worker.....but it will come. I will hopefully go on mission to discuss next year's activities and budgets with colleagues working in small antenna offices around the Nort [sic!] 
This is a pre-print version;

The final version of the article was published in Evaluation and Program Planning Volume 35, Issue 1 (2012), pp.148-153 and can be accessed at http://dx.doi.org/10.1016/j.evalprogplan.2010.11.006

Kivu province - in Rutshuru, Kitchanga, Masisi, Beni and Lubero'(Welcome to my blog - first impressions from Goma, http://jzech.wordpress.com/, 1 November 2009).

Not far away from Bintu's home country, Joahnnes, a young UNHCR officer, is sharing his initial impressions of his first 'mission' abroad from the Geneva headquarters in his blog. His observations sound familiar to many who have been working in a conflict or post-war environment. He himself describes his environment as the 'micro-cosmos of a UN worker' and his forthcoming 'mission' to the 'field' will be to discuss 'activities' and 'budgets' - measurables that can be monitored and may be evaluated by an outside consultant who is likely to never 'really arrive' when he or she is carrying out her research and writes and report about the activities and budgets of 'antenna offices'.

John in 'Peaceland'

The final vignette comes from a friend I will call 'John'. John is working for a UN agency in Asia and shared some of his first impressions when he returned to the country by EMail:

First 10 days in the office has been fascinating but totally overwhelming as well. As with [name of previous employer; a multilateral donor] most of the work is management (update the annual plan, fill in leave sheets, input to a document for HQ, revise the budget, amend submission to peace fund for Local Peace Committees, process a contract extension, give comments back on the audit report, endless donor coordination meetings [I think there are 5 separate meetings on constitution building my unit is supposed to 
This is a pre-print version;

The final version of the article was published in Evaluation and Program Planning Volume 35, Issue 1 (2012), pp.148-153 and can be accessed at http://dx.doi.org/10.1016/j.evalprogplan.2010.11.006

attend...]) With nice irony the first morning “on my own” (I had a 3 day handover with [name of predecessor]) was [a location-specific general strike] so we were in the UN convoy to get to the office and stopped at [landmark outside the office] by an angry crowd not happy at the UN breaking the [general strike]... that would have been real conflict prevention if I'd jumped out of the vehicle and found a solution. But instead I was getting stressed as I would miss the meeting to brief resident coordinator on minimum standards for UN engagement in discharge of minors from the cantonments....

John is a more experienced peacebuilder and his reflections on his work routines actually prevent him from doing some conflict resolution work are again not uncommon to international donor agency staff. And although Bintu is not directly affected by international peacebuilding, all three vignettes raise some broader issues about the personal dimension of living and working in conflicts, transnational professionalism and spatial dimensions of international peacebuilding - issues that are currently ignored when peacbuilding is evaluated. Caddell and Yanacopoulous, based on field work in Nepal and Uganda, describe how 'organizational learning' in conflict zones is accompanied by a process of ignoring the personal dimension of local and international staff:

This silencing process [in organisational processes] is further accentuated by the shift from the personal, emotional and experiential dimensions of working in conflict situations to the technical, more distanced and rational language of programme reports and policy documentation. Institutional pressures to demonstrate success, to be seen to be 
This is a pre-print version;

The final version of the article was published in Evaluation and Program Planning Volume 35, Issue 1 (2012), pp.148-153 and can be accessed at http://dx.doi.org/10.1016/j.evalprogplan.2010.11.006

acting within certain parameters and frameworks, may well militate against broader and more open discussion of practical and political dynamics of the conflict. Such an analysis highlights the need to move beyond calls for more informed analysis of conflict contexts that pervades much of the literature in the field (2006: 575-576).

As important as it is to keep organizational strategies in mind, the vignettes also give a sense of the transnationality of Johannes and John, their movement between headquarters, capital cities, regional offices and 'the field'. Transnational life- and work-styles (Fechter 2007; Garsten 2008) and related subjects, e.g. global travel and movement (Amit 2007), family and gender issues (Coles and Fechter 2007) or biographical research into diplomatic or humanitarian communities (Roth 2006) have gained some momentum in sociological and anthropological research. Whereas most of the examples are engaging with the corporate world rather than international development these are important contributions that give a 'face' to abstract notions of 'multi-sitedness' or a global 'community' of (peacebuilding) professionals. These processes of depolitication and living and working in post-conflict 'non-places' shaped by the aid industry can even be put into the bigger picture of (post-)modernity and peacebuilding work as a particular form of participating in a 'consumerist' peacebuilding lifestyle that sometimes resembles Bauman’s exploration into ‘liquid modernity’: ‘In the words of Liisa Uusitalo,

Consumers often share physical spaces of consumption such as concert or exhibition halls, tourist resorts, sports activity sites, shopping malls and cafeterias, without having any actual social interaction.” Such spaces encourage action, not inter-action. Sharing 
This is a pre-print version;

The final version of the article was published in Evaluation and Program Planning

Volume 35, Issue 1 (2012), pp.148-153 and can be accessed at http://dx.doi.org/10.1016/j.evalprogplan.2010.11.006

physical space with other actors engaged in a similar activity adds importance to the action, stamps it with the 'approval of numbers' and so corroborates its sense, justifies it without the need to argue' (Bauman 2000: 97).

This is just a short overview into the 'realities' that those who travel and evaluate, live and advice donor organizations encounter; realities that are currently not addressed by the managerial approaches to evaluation peacebuilding as the following paragraph elaborates.

\section{Peacebuilding workstyles}

The central argument is that M\&E in peacebuilding and (post-)conflict development work has succumbed to mainstream managerial aid approaches rather than taking the opportunity to use such work for challenging dominant results-based management discourses.

'Within the field of conflict prevention, there is still a quest to find appropriate methods and ways in dealing with planning, monitoring and evaluation’ (Scheers 2008: 5). 'In conclusion, efforts have been made to plan, monitor and evaluate conflict prevention activities. Nevertheless, there is more to be done to improve PM\&E practice in this field' (ibid: 57). Goele Scheers, who works for a leading NGO in the field of conflict prevention that has been working on these issues for more than a decade, is not alone in her quest for knowledge and tools for peace-related activities. A few years earlier Cordula Reimann and Norbert Ropers reflected on the 'discourses on peace practice' and concluded: 'Much of the critical introspection of the last couple of years went hand in hand with the development of "new" conflict sensitive approaches and frameworks. The two best-known and widely implemented approaches to date are outlined in "Do No Harm" 
This is a pre-print version;

The final version of the article was published in Evaluation and Program Planning Volume 35, Issue 1 (2012), pp.148-153 and can be accessed at http://dx.doi.org/10.1016/j.evalprogplan.2010.11.006

(Anderson 1999) and "Peace and Conflict Impact Assessment”' (2005: 38, my emphasis). And in one recent comprehensive overview and practical guide, Thania Paffenholz and Luc Reychler, two experienced researchers and practitioners, sum up the earlier debates not without concluding that discussions about evaluation are far from over: 'The debate on lessons learned occurring within the field of peacebuilding since the late 1990s has recently matured with the consequence of shifting discussions toward the need to further professionalize intervention planning and evaluation' (2007: 34). These are just three snapshots from the debates around evaluation and peacebuilding, but they already highlight important aspects of the discussion. In the following paragraph I will focus on three, interlinked aspects that partly explain this 'state of art' debate and why it is important and difficult to break through the discursive 'glass ceiling': First, evaluation of peacebuilding has to be put into a critical perspective with the wider peacebuilding discourse; second, the debates shed some light on a community of 'flexians', professionals who flexibly adjust and interpret this discourse in a specific organizational, programmatic and academic environment and third, a tactic to avoid more far reaching debates about the impact of peacebuilding and the role of external actors.

To challenge the peacebuilding project from a Foucauldian discourse perspective as an instrument to achieve control over 'fragile' and 'dangerous' places has been undertaken by different researches (e.g. Denskus 2007). Central to such an interpretation of various elements of peacebuilding (e.g. election support, liberal economic reforms and 'good governance' promotion) is the idea that order can be established through a variety of measuring, counting and policing devices (Löwenheim 2008, Rossi 2004). Measuring the 'impact' of a peacebuilding 
This is a pre-print version;

The final version of the article was published in Evaluation and Program Planning Volume 35, Issue 1 (2012), pp.148-153 and can be accessed at http://dx.doi.org/10.1016/j.evalprogplan.2010.11.006

project therefore seems logical and suitable. Even the comprehensive discussions about PCIA that are published by the Berghof Research Centre in their Handbook for Conflict Transformation (http://www.berghof-handbook.net/std_page.php?LANG=e\&id=19\&parent=5) talk about the dangers of 'commodification' of the approach and highlight important critical aspects, but they stop one step short of a fully discursive analysis:

The current focus on so-called 'gaps' by many within the academic, policy and operational communities may inhibit us from critically assessing the structures, processes and standard operating procedures, that currently define and limit bilateral and multilateral developmental, humanitarian institutions / organisations. The logic and rules of the conventional humanitarian, development and peacebuilding 'game' often serve to undercut peacebuilding impacts / outcomes. The conventional programming logic of efficiency, product-over-process, linearity, "results-based management”, Northerncontrol (under the guise of monitoring and accountability) are at odds with what is often required for sustainable, effective, humanitarian / developmental / peacebuilding initiatives, e.g. approaches which are organic, process-oriented, community-controlled, responsive and non-linear' (Bush 2003: 50).

Only in an unpublished MA dissertation of a researcher who now works at the Berghof Foundation puts the PCIA debates into a broader perspective of knowledge creation and utilisation, technologisation and institutional power: 
This is a pre-print version;

The final version of the article was published in Evaluation and Program Planning Volume 35, Issue 1 (2012), pp.148-153 and can be accessed at http://dx.doi.org/10.1016/j.evalprogplan.2010.11.006

The current PCIA debate shows the problems of technologisation and also depolitication of the debate and that the methods for reflecting on impact are far more than just a “toolkit”. The example of the World Bank shows that such tools contribute to a specific form of knowledge creation and exercise of power [...] that have concrete social and political effects. [...]' (Koerppen 2005: 52-53).

A similar analysis could be conducted for other approaches, e.g. the 'Reflecting on Peace Practice’ (Anderson 2003), ‘Aid for Peace’ (Paffenholz and Reychler 2007) or ‘Aiding Peace?’ (Goodhand 2006), and would likely come to similar conclusions as the models and tools all operate in the same context of assessing donor-support peacebuilding work in post-conflict societies.

One should be careful, though, to take the published discourse at face value, i.e. wholeheartily believing in written documents, published debates or (stereo)typical dichotomies of 'knowledge-seeking' academics, 'overpaid' international consultants and advisors or 'shortsighted' programme staff. There is a remarkable (and hardly discussed) political economy behind the peace industry that is managed by fluid personalities who often shift positions and organisations and are as much part of a volatile funding environment as many other parts of the development knowledge economy. So these broader patterns of academic knowledge production, 'influencing policy-making' and maintaining a complex web of relationships in this industry are reflected in the peacebuilding community and the discourses around evaluation tools and approaches. There are neither real 'gaps in knowledge' as the consistently high output of critical 
This is a pre-print version;

The final version of the article was published in Evaluation and Program Planning Volume 35, Issue 1 (2012), pp.148-153 and can be accessed at http://dx.doi.org/10.1016/j.evalprogplan.2010.11.006

voices on the liberal peacebuilding project shows (MacGinty 2008; Richmond and Franks 2007; Sriram 2007), nor big structural problems in getting this seemingly objective knowledge translated into policy and practice. Numerous NGOs and 'Think Tanks' in Brussels, Geneva, New York, London or Berlin have organized numerous workshops and conferences and have produced numerous briefings, documents, working papers and newsletters on almost every aspect of the discourse. And this is only the 'official' side of the economy. Internal handbooks, numerous ‘classic' monitoring reports and conservative evaluations, regular 'backstopping' by affiliated consultants and/or academics, organizational restructuring and knowledge management efforts have been taken place in every large bilateral and multilateral aid organization - before they have been shared and discussed at the OECD or the World Bank. 'We' know enough, share enough and have a variety of tools ready to use. What is less discussed is the role of the bright graduate intern who is looking for a 'real' job to start paying back her student loans for her expensive MA programme, the academic colleague who is offered research money for a large project on civil society involvement in post-conflict societies or the young father who is offered a well-paid, desk-based consultancy to work on a DRR handbook for an UN agency although they told him that the exercise is not about the contents or to produce guidance for staff, but more of a PR tool to show (off) expertise and lobby within the UN system for more funds on this subject. Like Bintu, Johannes and John, these people exist and their individual stories and relationship deserve more attention by research to get a more in-depth view of how policy processes are actually working. The complexities behind the political economy are seldom discussed, but it is important to keep in mind that relationships, power relations and micro 
This is a pre-print version;

The final version of the article was published in Evaluation and Program Planning

Volume 35, Issue 1 (2012), pp.148-153 and can be accessed at http://dx.doi.org/10.1016/j.evalprogplan.2010.11.006

dynamics are very influential, but not adequately researched and discussed in the light of producing 'hard evidence' through evaluations frameworks and monitoring tools. This is also not limited to the global North. Anthropological research from war-zones and immediate post-war societies shows how complex the challenge is and that 'disarming combatants' or 'preparing free and fair elections' are merely products that the international peacebuilding industry wants to 'sell' in the aftermath of conflict.

This brings me to the last of the three points about the 'avoidance' of critical topics and debates. Even if a 'discourse coalition' actively meets, conferences and writes newsletters, they still tend to avoid fundamentally challenging debates about the telos of peacebuilding. The recently published 'Open letter to peacebuilders’ (Fisher and Zimina 2008) is a rare sign of stimulating a fresh debate, but it remains to be seen what the follow-up implication for example for monitoring or evaluation will be.

\section{Conclusion}

It is not enough to tell stories when engaging with violent conflict or post-conflict situations. But what this short article want to highlight is that most of the current evaluation practice follows a strict development and peacebuilding discourse that favours measurable outputs, glossy reports and treating the evaluation process as a 'non-activity' - an activity that is often not supposed to engage participants or raise fundamental questions. Martina Fischer, a senior researcher with the aforementioned Berghof Foundation, outlines her vision for evaluating peace practice as follows: 'The challenge lies in asking for more than just short-term evaluations 
This is a pre-print version;

The final version of the article was published in Evaluation and Program Planning Volume 35, Issue 1 (2012), pp.148-153 and can be accessed at http://dx.doi.org/10.1016/j.evalprogplan.2010.11.006

[consultants travelling to the field for a short period of time] and establish a process-oriented actions research with a focus on learning' (2006: 163). Using the full range of qualitative social science research is necessary-but not impossible. But a broader range of methodologies is not sufficient and should not be de-linked from the second aspect of the peacebuilding discourse paragraph: The importance of relationships, personal attitudes and professional mindsets (see for example Eyben 2006; Chambers 2006, 2007). As 'reflective practice’ and methods gain more prominence in development work (Brock and Pettit 2007), teaching and learning (Taylor et al 2006) it should also become part when engaging with violent situations-even if fast-paced transitions seem unsuitable for reflection or the challenges of dealing with violence seem impossible for quiet introspection. But only if peace practitioner (whether based in the global North or South) dare to include the personal dimension will they be able to understand, challenge and change the structural violence and power relations that hide behind labels ('spoilers', 'girl soldiers', 'civic engagement') or the visible and measurable.

\section{Ways forward}

In this final part of the article I will highlight three areas from the paradigmatic to the more practical that deserve more attention with regards to discussing and implementing monitoring and evaluation in peacebuilding.

1. Complexity thinking and new methodologies in qualitative research

Complexity science" is a term used to describe a set of concepts, principles, propositions and ideas that have emerged and clustered together over the course of the 20th century, [...] 
This is a pre-print version;

The final version of the article was published in Evaluation and Program Planning Volume 35, Issue 1 (2012), pp.148-153 and can be accessed at http://dx.doi.org/10.1016/j.evalprogplan.2010.11.006

seeking the answers to some fundamental questions about living, adaptable, changeable systems’ (Ramalingam and Jones et al 2008:1).

Although some initial research has taken place in the aid and humanitarian communities, peace research and international peacebuilding has not engaged with complexity thinking yet. This is a particularly caveat in the policies and practices of large donor organizations and without further acknowledgement of the systemic nature of post-conflict situations, their complex linkages and the active roles of the actors involved - from street vendors to international consultants - any manual or toolbox can only fiddle with some of the symptoms on the surface of assessing peacebuilding interventions and their impact. To avoid the 'tool-ification' of complexity thinking, any approach fundamentally needs to challenge the underlying assumption of social scientific research that are used by donor organizations or evaluators. Treating evaluation processes as a 'performance' in an anthropological sense, i.e. what Grimes describes as the 'showing of a doing' (2003: 35), is important to understand the complex relationships of projects or programmes as Dirksmeier and Helbrecht explain, this requires a completely different positionality of the researcher and her/his views on causality: 'The social scientific observer becomes even part of the performance him/herself. The research process as a whole is (part of the) performance. This "holistic" conception replaces the "laboratory" situation for data acquisition with separate roles of the "researched" person and research observer' (Dirksmeier and Helbrecht 2008: 13). The challenges in post-conflict environments demand such a fundamental rethinking of 'our' approaches of telling the stories of social change as they are happening. 
This is a pre-print version;

The final version of the article was published in Evaluation and Program Planning Volume 35, Issue 1 (2012), pp.148-153 and can be accessed at http://dx.doi.org/10.1016/j.evalprogplan.2010.11.006

2. Exploring the full space of war to peace transitions with ethnographic methods

In a recent article that questions ‘peace by bureaucratic means', Goetschel and Hagmann identify 'ethnography of peacebuilding’ as one area for a more empirical approach to peacebuilding (2009: 68). They are right that '[p]eacebuilding transformed peace into an apolitical concept the meanings, substance and causal beliefs of which are taken for granted and less and less debated among practitioners and policy-makers' (ibid: 66), but they are not explicit enough in unpacking the 'bureaucratic' assumptions that inevitably comprise 'bureaucratic' models of monitoring or evaluation: The 'lifestyle' of international peacebuilders, the spatial changes of capital cities of post-conflict countries and many other issues are still under-explored. Recent anthropological and sociological research, e.g. on the Wall Street (Ho 2009), spatial formations of financial cities (Thrift 1996) or aspects of academia (Blum 2009, Tuchman 2009) is only a very small indication of the potential to further explore the institutions, people, mindsets and discourses behind the concept of 'peacebuilding'. In her anthropological investigation of the Wall Street culture, Karen Ho uses Hugh Gusterson's concept of 'polymorphous engagement' to outline her methodology in a way that could also be very interesting for peacebuilding-related institutions, people and projects:

[Gusterson] de-emphasizes participant observation as an often impossible method in studying up. Instead, he writes, the ethnography of the powerful needs to consist of "interacting with informants across a number of dispersed sites, not just in local communities, and sometimes in virtual form; and it means collecting data eclectically from a disparate array of sources in 
This is a pre-print version;

The final version of the article was published in Evaluation and Program Planning

Volume 35, Issue 1 (2012), pp.148-153 and can be accessed at http://dx.doi.org/10.1016/j.evalprogplan.2010.11.006

many different ways [such as]...formal interviews...extensive reading of newspapers and official documents...careful attention to popular culture”, as well as informal social events outside the actual corporate office or laboratory (Ho 2009: 19).

3. A framework for learning and new tools for engagement

Such debates and quests for an expanded understanding of 'peacebuilding' do not need to be abstract academic debates or playground for anthropologists. The international NGO Actionaid has been part of discussions of their 'Accountability, Learning and Planning System' (ALPS) as part of their organisational learning and accountability to their diverse constituencies for many years (e.g. Scott-Villiers 2002, Vincent and Byrne 2006, Mowles 2008). Although discussing values and accountability may be a more prominent debate in the non-profit sector, nothing prevent bilateral or multilateral donor agencies to start a similar discussion about their peacebuilding work. Qualitative methods and researchers could facilitate such learning processes that could give a ' 360 degree' view of organisational processes and staff behaviour and its impact on positive social change in post-conflict countries.

I am deliberately mentioning blogs as important sources of information and initial discussions right from the beginning of the article, because they are part of the growing technological advances that currently seem to be under-used in the quest to submit a 'draft report' on time: Blogs, participatory video, photography etc can all play a more significant role to capture the challenges of peacebuilding with qualitative methods beyond the 'bureaucratic' and 'indoor' imperatives of short reports, PowerPoint presentations and ritualized meetings. 
This is a pre-print version;

The final version of the article was published in Evaluation and Program Planning Volume 35, Issue 1 (2012), pp.148-153 and can be accessed at http://dx.doi.org/10.1016/j.evalprogplan.2010.11.006

\section{References}

Amit, V. (2007). Going first class?. New approaches to privileged travel and movement. Oxford: Berghahn Books.

Anderson, M., Olson, L. \& Doughty, K. (2003). Confronting War: Critical Lessons for Peace Practitioners. Cambridge, MA: The Collaborative for Development Action.

Bauman, Z. (2000). Liquid modernity. Cambridge: Polity Press.

Blum, S.D. (2009). My Word! Plagiarism and College Culture. Ithaca: NY: Cornell University Press.

Brock, K. \& Petitt, J. (2007). Springs of participation. Creating and evolving methods for participatory development. Rugby: Practical Action.

Bush, K. (2003). PCIA Five Years On. The Commodification of an Idea. In: Austin, A., Fischer, M. \& Wils, O.: Peace and Conflict Impact Assessment. Critical Views from Theory and Practice. Berlin: Berghof Research Center for Constructive Conflict Management, 37-51.

Caddell, M. \& Yanacopulos, H. (2006) Knowing but not knowing. Conflict, development and denial. Conflict, Security \& Development, 6(4), 557-579.

Chambers, R. (2006) Poverty Unperceived. Traps, Biases and Agenda. IDS Working Paper 270. Brighton: Institute of Development Studies. 
This is a pre-print version;

The final version of the article was published in Evaluation and Program Planning Volume 35, Issue 1 (2012), pp.148-153 and can be accessed at http://dx.doi.org/10.1016/j.evalprogplan.2010.11.006

Chambers, R. (2007) Out of the closet, into the open. Professionalism, power and the personal in development. World Review of Science, Technology and Sustainable Development, 4 (4), 385-394.

Coles, A. \& Fechter, A. (2008) Gender and family among transnational professionals. New York; London: Routledge.

Denskus, T. (2007). Peacebuilding does not build peace. Development in Practice, 17(4\&5), 656-662.

Dirksmeier, P. \& Helbrecht, I. (2008). Time, Non-representational Theory and the "Performative Turn”. Towards a New Methodology in Qualitative Social Research. Forum Qualitative Sozialforschung / Forum: Qualitative Social Research, 9(2), Art 55, available online at http://nbnresolving. de/urn:nbn:de:0114-fqs0802558.

Eyben, R. (2006). Relationships for Aid. London: Earthscan.

Fechter, A. (2007). Transnational lives. Expatriates in Indonesia. Aldershot: Ashgate.

Fischer, M. (2006). Civil Society in Conflict Transformation. Ambivalence, Potentials and Challenges. In: Bloomfield, D., Fischer, M. \& Schmelzle, B.: Berghof Handbook for Conflict Transformation. Berlin: Berghof Research Center for Constructive Conflict Management, Available online at: http://www.berghof-handbook.net. 
This is a pre-print version;

The final version of the article was published in Evaluation and Program Planning Volume 35, Issue 1 (2012), pp.148-153 and can be accessed at http://dx.doi.org/10.1016/j.evalprogplan.2010.11.006

Fischer, M. (2006). Friedensarbeit zwischen Kurzzeit-Evaluierung, Prozessbegleitung und Aktionsforschung. In: Calliess, J.: Tun wir das, was wir tun, richtig? Tun wir das Richtige? Evaluation in der zivilen Konfliktbearbeitung. Evangelische Akademie Loccum, 159-171.

Fisher, S. \& Zimina, L. (2008). Just Wasting Our Time?. An Open Letter to Peacebuilders. Available online at http://lettertopeacebuilders.ning.com/.

Garsten, C. (2008). Workplace vagabonds. Career and community in changing worlds of work. Basingstoke: Macmillan.

Goetschel, L. \& Hagmann, T. (2009). Civilian peacebuilding. Peace by bureaucratic means? Conflict, Security \& Development, 9 (1), 55-73.

Goodhand, J. (2006). Aiding Peace? The Role of NGOs in Armed Conflict. Intermediate Technology Publications: Rugby.

Grimes, R. (2003) Ritual theory and the environment. In W. Heim, B. Szerszynski \& C. Waterton (Ed.): Nature performed. Environment, culture and performance. Oxford: Blackwell, 31-45

Ho, K. (2009). Liquidated. An Ethnography of Wall Street. Durham, NC: Duke University Press.

Jeffrey, A. (2007). The geopolitical framing of localized struggles. NGOs in Bosnia and Herzegovina. Development and Change, 38(2), 251-274. 
This is a pre-print version;

The final version of the article was published in Evaluation and Program Planning Volume 35, Issue 1 (2012), pp.148-153 and can be accessed at http://dx.doi.org/10.1016/j.evalprogplan.2010.11.006

Körppen, D. (2005). Peace and Conflict Impact Assessment. Eine Analyse aktueller Konzepte und Methoden und ihrer Relevanz fuer friedens- und entwicklungspolitische Interventionen. Magdeburg: Otto-von-Guericke Universität.

Löwenheim, O. (2008). Examining the State. A Foucauldian perspective on international 'governance indicators'. Third World Quarterly, 29(2), 255-274.

Mac Ginty, R. (2008). No War, No Peace. The Rejuvenation of Stalled Peace Processes and Peace Accords. Houndmills: Palgrave Macmillan.

Mosse, D. \& Lewis, D. (2005). The Aid Effect. Giving and Governing in International Development. London: Pluto Press.

Mowles, C. (2008). Values in international development organisations. Negotiating nonnegotiables. Development in Practice, 18,(1), 5-16.

Nordstrom, C. (2004). Shadows of War. Violence, Power, and International Profiteering in the Twenty-First Century. Berkeley, CA: University of California Press.

Paffenholz, T. \& Reychler, L. (2007). Aid for Peace. A guide to planning and assessment for conflict zones. Baden-Baden: Nomos.

Pearce, J. (2007). Violence, Power and Participation. Building Citizenship in Contexts of Chronic Violence. Brighton: Institute of Development Studies. 
This is a pre-print version;

The final version of the article was published in Evaluation and Program Planning Volume 35, Issue 1 (2012), pp.148-153 and can be accessed at http://dx.doi.org/10.1016/j.evalprogplan.2010.11.006

Pouligny, B. (2005). Civil Society and Post-Conflict Peacebuilding. Ambiguities of International Programmes Aimed at Building 'New' Societies. Security Dialogue, 36 (4), 495-510.

Ramalingam, B., Jones, H., Reba, T. \& Young, J. (2008). Exploring the science of complexit. Ideas and implications for development and humanitarian efforts. London: Overseas Development Institute.

Reimann, C. \& Ropers, N. (2005). Discourses on Peace Practices. Learning to Change by Learning from Change? In: Van Tongeren, P., Brenk, M., Hellema, M. \& Verhoeven, J.: People Building Peace II-Successful Stories of Civil Society. Boulder, CO: Lynne Rienner, 29-43.

Richards, P. (2005). No Peace, No War. An Anthropology of Contemporary Armed Conflict. Athens, OH/Oxford: Ohio University Press/James Currey.

Richmond, O. P. \& Franks, J. (2007). Liberal Hubris? Virtual Peace in Cambodia. Security Dialogue, 38(1), 27-48.

Rossi, B. (2004). Revisiting Foucauldian Approaches. Power Dynamics in Development Projects. Journal of Development Studies, 40(6), 1-29.

Roth, S. (2006). Humanitaere Hilfe. Zugaenge und Verlaeufe. In: Kreutzer, F. \& Roth, S.: Transnationale Karrieren. Biographien, Lebensführung und Mobilität. Wiesbaden: VS Verlag fuer Sozialwissenschaften, 100-121. 
This is a pre-print version;

The final version of the article was published in Evaluation and Program Planning Volume 35, Issue 1 (2012), pp.148-153 and can be accessed at http://dx.doi.org/10.1016/j.evalprogplan.2010.11.006

Scheers, G. (2008). Assessing Progress on the Road to Peace. Planning, Monitoring and Evaluating Conflict Prevention and Peacebuilding Activities. The Hague: European Centre for Conflict Prevention/Global Secretariat of the Global Partnership for the Prevention of Armed Conflict.

Sriram, C. L. (2007). Justice as Peace? Liberal Peacebuilding and Strategies of Transitional Justice. Global Society, 21(4), 579-591.

Taylor, P., Deak, A., Pettit, J. \& Vogel, I. (2006). Learning for Social Change. Exploring concepts, methods and practice. Brighton: Institute of Development Studies.

Utas, M. (2005) Victimcy, Girlfriending, Soldiering. Tacit Agency in a Young Woman's Social Navigation of the Liberian War Zone. Anthropological Quarterly, 78 (2), 403-430. 